\title{
RESEARCH OF DYNAMICS OF INFORMATION DISTRIBUTION PROCESSES BASED ON DIFFUSION HYBRID MODELS
}

Ivohin E. V. - Dr. Sc., Professor, Professor of the Department of System Analysis and Decision Support Theory, Taras Shevchenko National University of Kyiv, Kyiv, Ukraine.

Adzhubey L. T. - PhD, Associate Professor, Associate Professor of the Computational Mathematics Department, Taras Shevchenko National University of Kyiv, Kyiv, Ukraine.

Gavrylenko O. V. - PhD, Associate Professor, Associate Professor of the Department of Automated Information Processing and Control Systems, National Technical University of Ukraine "Igor Sikorsky Kyiv Polytechnic Institute", Kyiv, Ukraine.

Naumenko Yu. O. - PhD, Junior Researcher of the Department of System Analysis and Decision Support Theory, Taras Shevchenko National University of Kyiv, Kyiv, Ukraine.

\section{ABSTRACT}

Context. Solving of the problem of formalization and study of the development of the process of information dissemination over time and its impact on the society is very important for ensuring information security. It is necessary to use a fundamentally new tool that will adequately reflect the state of the dynamic component of the process of information dissemination.

Objective. The goal of the work is the research of mathematical models of processes of dissemination to model the dynamics of changes in the levels of influence of information within different target groups.

Method. This paper proposes an approach to formalize hybrid mathematical models of the dynamics of information process propagation in the target group on the basis of diffusion models. In order to improve the adequacy and reliability of the results obtained from the constructed models, it is proposed to apply hybrid systems based on diffusion models and dynamic models describing the process of changing the size of the contingent of the information dissemination environment. The proposed method allows to simulate the dynamic processes of observing the level of information impact based on the solution of inhomogeneous diffusion equations, the change of intervals of a spatial variable in which is determined by additional relations in the form of a system of differential equations. The scalar case of $\mathrm{f}$ homogeneous and inhomogeneous diffusion equation is considered under the condition of onedimensional representation of the target group contingent. The examples of application of this approach are given, the results of numerical experiments are analyzed.

Results. The developed technique allows to obtain estimates of the level of information dissemination in the target group based on the use of diffusion process models.

Conclusions. The conducted experiments have confirmed the existence of sufficient adequacy of model data and data obtained as a result of real observations of the processes of change in the perception of information within specific target population groups. The prospects for further research are the development of new diffusion-type models that formalize the different nature of the influence of external factors on the processes of information dissemination.

KEYWORDS: information, dissemination, method of analogues, diffusion hybrid models.

\section{NOMECLATURE}

$u(x, t)$ a function of the level of information dissemination;

$x$ a part of population which magnitude does not exceed a predetermined value;

$t$ time;

$y_{1}(t)$ a part of the population that is sensitive to the influence of information;

$y_{2}(t)$ a part of the population which is already under the influence of information;

$y_{3}(t)$ a part of the population which is indifferent to information influence;

$y_{1}^{0}$ a initial condition for $y_{1}(t)$;

$y_{2}^{0}$ a initial condition for $y_{2}(t)$;

$y_{3}^{0}$ a initial condition for $y_{3}(t)$;

$x_{\Gamma}(t)$ a part of the population that is affected by the information;

$k(t)$ a coefficient of information penetration; $f(x, t)$ a functions of external informational influence;

$g(t)$ a function of changing the information level;

$F(u)$ a function of changing the level of information dissemination;

$a$ a time dependent parameter;

$c$ some constant;

$X(x)$ unknown integrand;

$\mu$ a proportionality coefficient for the information penetration;

$\alpha$ a proportionality coefficient for the parameter $a$;

$\beta$ a proportionality coefficient for the functions of the influence;

$X_{o}(x)$ a total solution of the homogeneous equation;

$X_{H}(x)$ a partial solution of the inhomogeneous equation;

$\gamma$ a proportionality coefficient;

$\lambda$ a velocity of curve moving;

$U(z)$ a solution form for $u(x, t)$;

$z$ a new variable $z=x+\lambda t$. 


\section{INTRODUCTION}

One of the approaches, within the framework of which both the classical and the system method of modeling the behavior of objects (systems) is effectively implemented, is a method based on the application of formal (biological, chemical or physical) analogies in the process of dynamics formalizing [1-3]. The practical application of the analogy method begins with the development of the first approximation of the model and consists in converting the mechanistic analogue to the mathematical model of the process under study. The next stage involves the use of mathematical tools to analyze the model. The mathematical results obtained in the process of computational experiments go through the subsequent stage of reverse interpretation in terms of the analogy system. And finally, it is necessary to evaluate the results obtained on the basis of the model in order to decide whether they are satisfactory - formally substantiated and sufficient to achieve the goals.

The tasks of the analytical processing of modern information flows and their influence require solving the problems of studying the dynamics of information dissemination processes based on simulation and forecasting tools. The development of models and methods for simulating information impacts, taking into account the processes of information dynamics, can effectively solve important communication problems, significantly increase the level of information security of the state, and tactically and strategically predict the development of information confrontation events. A constructive method for analyzing the dynamics of information dissemination processes can be proposed based on the use of a fundamentally new toolkit using the method of analogy and hybrid models, which allows adequately reflecting the state of the dynamic component of the process of disseminating information [4-9].

The object of study is the process of dissemination and influence of information in the target group.

The subject of study is the development of hybrid models of diffusion type for process modelling of information dissemination taking into account the influence of external factors.

The purpose of the work is the research of mathematical models of processes of information dissemination to model the dynamics of changes in the levels of influence of information within different target groups.

\section{PROBLEM STATEMENT}

We will model changes in the level (concentration) of information in a population with the help of the diffusion equation [10], assuming that this process is similar to the spread of a substance (infection) over a specific time period $t \in[0, T]$ and can be described by a scalar equation

$$
\partial u / \partial t=-k(t) \partial^{2} u / \partial x^{2}
$$

with the initial condition $u(x, 0)=0,0 \leq x \leq 1$, and the boundary conditions $u(0, t)=u_{0} \geq 0, u(1, t)=0, t \in[0, T]$.

(C) Ivohin E. V., Adzhubey L. T., Gavrylenko O. V., Naumenko Yu. O., 2020 DOI 10.15588/1607-3274-2020-2-13

\section{REVIEW OF LITERATURE}

The substantiation of the correctness of the use of diffusion models for describing the dynamics of information dissemination processes, which is presented in [6], allows to extend the simulation result by taking into account the hybridity of finite models.

Obviously, the dissemination of information in society, thoughts on social networks, advertising products and other information processes are largely similar to the processes of distribution (penetration) of a substance that diffuses in a certain environment. It is assuming that the environment is homogeneous and the area of permissible information dissemination based on structural extension of the model by a hybrid subsystem [7] can be calculated with the help of appropriate solutions of this subsystem. Such a hybrid model has proved to be quite effective for describing the states of different target groups of people affected by the information flow [8]. The natural generalization of the proposed approach in this case is to formalize the impact on the dynamics of the dissemination of information processes by external sources or means of influence.

The substantiation of the correctness of the use of diffusion models for describing the dynamics of information dissemination processes, which is presented in [9], allows to extend the simulation result by taking into account the hybridity of finite models. It is advisable to consider the hybridity of the structure of the model with tracking the dynamics of the quantitative composition of the target groups, within which the level of information dissemination and impact is monitored.

\section{MATERIALS AND METHODS}

We believe that the contingent of the target population is formed of 3 subgroups based on the perception of information. We identify the part of the population that is sensitive to the influence of information $y_{1}(t)$, the part which is already under the influence of information $y_{2}(t)$ and the part which is indifferent to information influence $y_{3}(t)$. Then, using the Bailey model [11], the dissemination of appearance information

$$
\begin{aligned}
& \dot{y}_{1}(t)=-y_{1}(t) y_{2}(t), \\
& \dot{y}_{2}(t)=y_{1}(t) y_{2}(t)-y_{2}(t), \\
& \dot{y}_{3}(t)=y_{2}(t),
\end{aligned}
$$

with the initial condition $y_{1}(0)=y_{1}^{0} ; y_{2}(0)=y_{2}^{0}$; $y_{3}(0)=y_{3}^{0}$, where the total of cure and disease rates are considered to be 1, $y_{1}(t)+y_{2}(t)+y_{3}(t)=1, t \geq 0$, there a system of differential equations that describes the process of information dissemination in the target population can be written. Their solutions determine the dynamics of the rate values of individual subgroups.

With such assumptions, the maximum threshold value of $x_{\Gamma}, 0 \leq x_{\Gamma}(t) \leq 1$, will depend on the time, so we have $0 \leq x \leq x_{\Gamma}(t), \quad x_{\Gamma}(t)=y_{1}(t)+y_{2}(t), \quad$ where 
$y_{1}(t), y_{2}(t)$ - are the components of the solution of system (2). In this case, the coefficient of information penetration $k(t)$ will be proportional to the rate of change of the part of the population that is considered to be susceptible to the influence of external information, i.e.

$$
k(t)=\mu \dot{x}_{\Gamma}(t), \mu>0 .
$$

Given the cumulative nature of the information dissemination process in society, we will search for a partial solution of the diffusion equation (1) in the form

$$
u(x, t)=\int_{0}^{x} X(\xi) d \xi+a t,
$$

where the parameter $a$ for the impact over time for each point in time $t$ is considered proportional to the rate of change of magnitude $x_{\Gamma}(t)$, i.e. $a=\alpha \dot{x}_{\Gamma}(t), \alpha>0$.

Given the assumptions made, we rewrite the boundary conditions of model (1) in the form $u_{x}^{\prime}(0, t)=\alpha x_{\Gamma}(t) / \mu$, $u_{x}^{\prime}(x, t)=0, x_{\Gamma}(t) \leq x \leq 1, t \in[0, T]$.

It is clear that in this formulation, diffusion equation (1) has a special solution that can be obtained provided $x_{\Gamma}(t)=c, c$-some constant, $c \in[0,1]$. In other words, with the presence of a stationary process in the dynamics of the size of the contingent under the influence of information, the level of information dissemination in the group remains constant. This solution is trivial.

Supposing that $\dot{x}_{\Gamma}(t) \neq 0$ we have that at any given time $t \in[0, T]$ the diffusion equation has a partial solution of the form (4), for which the next ordinary first-order differential equation must be solved

$$
d X(x) / d x=-\alpha / \mu
$$

with the initial condition at the end of the interval $X\left(x_{\Gamma}(t)\right)=0$, the solution will be the function $X(x)=\alpha\left(x_{\Gamma}(t)-x\right) / \mu, 0 \leq x \leq x_{\Gamma}(t)$ [12]. In doing so, we get the value $X(0)=\alpha x_{\Gamma}(t) / \mu$, corresponding to the first boundary condition of the diffusion equation.

So, finally, for the arbitrary $\alpha>0$ and $\mu>0$ equation (1) has the solution of the form

$$
u(x, t)=\alpha\left(x\left(x_{\Gamma}(t)-x / 2\right) / \mu+\dot{x}_{\Gamma}(t) t\right)
$$

which at any point in time $t \in[0, T]$ determines the level of distribution of information within a subgroup $0 \leq x \leq x_{\Gamma}(t)$, the size of which is a fraction $x_{\Gamma}(t)$ of the total number $A$ of members of the group calculated by the system junctions (12) (below the values $x_{\Gamma}(t), \dot{x}_{\Gamma}(t)$ we consider the instantaneous values of magnitude $x_{\Gamma}(t)=y_{1}(t)+y_{2}(t)$ and its velocity which is obtained from (2) at any moment of time $t$ ).
This solution may be generalized. It follows from the initial conditions of system (2) that $x_{\Gamma}(0)=1$. This allows you to rewrite the layout of the solution $u(x, t)$ subject to the initial condition $u(x, 0)=0,0 \leq x \leq 1$ from diffusion equation (1).

Indeed, the function

$$
u(x, t)=\alpha\left(x\left(x_{\Gamma}(t)-x / 2\right) / \mu+\dot{x}_{\Gamma}(t) t\right)\left(1-x_{\Gamma}(t)\right),
$$

satisfies equation (1) and the initial and boundary conditions, which makes it possible to consider it as a general solution of the diffusion equation.

The dynamics of the dissemination process based on the use of hybrid application models should be considered in the light of the external impact on the process and, as noted above, by observing the quantitative composition of the target groups within which information is disseminated.

Simulation of changes in the level (concentration) of information within a target group within a specific time interval $t \in[0, T]$ taking into account the external sources or means of influence we will carry out by means of the inhomogeneous diffusion equation [10] of a scalar form:

$$
\partial u / \partial t=-k(t) \partial^{2} u / \partial x^{2}+f(x, t)
$$

with initial conditions $u(x, 0)=0,0 \leq x \leq 1$, and boundary conditions $\quad u_{x}^{\prime}(0, t)=g(t), \quad u_{x}^{\prime}(x, t)=0$, $x_{\Gamma}(t) \leq x \leq 1, t \in[0, T]$, where $k(t)$ is proportional to the rate of change of a part of the population that is considered vulnerable to the influence of external information, i.e. $k(t)=\mu \dot{x}_{\Gamma}(t), \mu>0$ and the behavior of magnitude $x_{\Gamma}(t)$ is described by the system of equations (2) [11].

It is clear that the formalization of external influence in the form of function $f(x, t)$ requires many complex factors (e.g., the influence of the media, rumors, quality and content of information) to be taken into account. To obtain models, it is possible to consider the low level of information exchange within the group, to model the external influence by some dynamic value or on the basis of analogies of physical processes (described, for example, by the laws of Nernst or Newton [13]).

Consider the case in which the level of information dissemination is influenced by the dynamics of change in the number of the perceiving subgroup. In this case, you can put $f(x, t)=\beta \dot{x}_{\Gamma}(t), \beta>0$. Given the cumulative nature of the information dissemination indicator in the target subgroup, we will look for a partial solution of the diffusion equation (8) in the form

$$
u(x, t)=\int_{0}^{x} X(\xi) d \xi+\alpha x_{\Gamma}(t),
$$

where we consider the parameter $\alpha \geq 0$. 
Given the assumptions made, we rewrite the boundary conditions of model (8) in the form $u_{x}^{\prime}(0, t)=$ $=(\alpha-\beta) x_{\Gamma}(t) / \mu, u_{x}^{\prime}(x, t)=0, x_{\Gamma}(t) \leq x \leq 1, t \in[0, T]$.

Substituting the function $u(x, t)$ into equation (8), we obtain the relation

$$
\alpha \dot{x}_{\Gamma}(t)=-\mu \dot{x}_{\Gamma}(t) X(x)+\beta \dot{x}_{\Gamma}(t) .
$$

As in the previous case, diffusion equation (8) has a special solution, which can be obtained by assuming $x_{\Gamma}(t)=c, c-$ some constant, and which is trivial.

Suppose that $\dot{x}_{\Gamma}(t) \neq 0$. Then, at each point in time $t \in[0, T]$, the diffusion equation has a partial solution of the form (9), for which it is necessary to solve the ordinary first order differential equation

$$
d X(x) / d x=-(\alpha-\beta) / \mu,
$$

with the initial condition defined at the end of the interval $X\left(x_{\Gamma}(t)\right)=0$ whose solution will be $X(x)=$ $=(\alpha-\beta)\left(x_{\Gamma}(t)-x\right) / \mu, 0 \leq x \leq x_{\Gamma}(t)$ [12]. In this case, we have the value $X(0)=(\alpha-\beta) x_{\Gamma}(t) / \mu$ corresponding to the first boundary condition of the diffusion equation (8).

Thus, finally, for arbitrary values $\alpha \geq 0, \beta>0, \mu>0$, equation (8) has the solution of the form

$$
u(x, t)=(\alpha-\beta)\left(x\left(x_{\Gamma}(t)-x / 2\right) / \mu\right)+\alpha x_{\Gamma}(t),
$$

which at any point in time $t \in[0, T]$ determines the level of distribution of information within the fraction of a subgroup $0 \leq x \leq x_{\Gamma}(t)$ whose size $x_{\Gamma}(t)$ from the total number of group members is calculated by the solutions of system (1) (by values $x_{\Gamma}(t), \dot{x}_{\Gamma}(t)$ we mean the instantaneous values of the magnitude and $x_{\Gamma}(t)=y_{1}(t)+y_{2}(t)$ its velocity obtained from (2) at time $t$ ).

It follows from the initial conditions of system (2) that $x_{\Gamma}(0)=1$. Then you can rewrite the form of the solution $u(x, t)$ taking into account the initial condition $u(x, 0)=0,0 \leq x \leq 1$ of the diffusion equation (8). Indeed, the function

$$
u(x, t)=\left((\alpha-\beta)\left(x\left(x_{\Gamma}(t)-x / 2\right) / \mu\right)+\alpha x_{\Gamma}(t)\right)\left(1-x_{\Gamma}(t)\right),
$$

satisfies equation (8) and the initial and boundary conditions, which allows us to consider it as a general solution of the diffusion equation (8) with $f(x, t)=\beta \dot{x}_{\Gamma}(t)$.

Another interesting case of using heterogeneous equation (8) to model the process of changing the level of information dissemination in the target group is to take into account the impact-dependent model that is directly re- lated to the dynamics of the group information level. Considering that the rate of change of the information layer for a given part of the group and at the moment given in the form $f(x, t)=F(u(x, t))$ is known, this influence $u(x, t)$ on the level of information dissemination can be formalized by the diffusion equation

$$
\partial u / \partial t=-k(t) \partial^{2} u / \partial x^{2}+F(u),
$$

where it is assumed that the function $F(u)$ is defined and continuous on $0 \leq u \leq 1$, differentiated by $u$ and satisfies the conditions

$$
\begin{aligned}
& F(0)=F(1)=0 ; \quad F(u)>0, \quad 0<u<1 \\
& \partial F(0) / \partial u=\gamma, \gamma>0 ; \quad \partial F(u) / \partial u<\gamma, 0<u \leq 1 .
\end{aligned}
$$

Here, as before, $0 \leq x \leq x_{\Gamma}(t)$, where $x_{\Gamma}(t)$ is determined by the solution of system (2).

We will assume that the information level in the influence group increases over time. Then from the last condition (16) it follows that at sufficiently small $u$ growth rate $F(u)$ is proportional to $u$ with coefficient $\gamma$. In addition, when $u$ is approaching 1 - the unit of growth $F(u)$ stops.

Suppose that at the initial moment of time the appearance of information leads to a process of its propagation, characterized by a velocity $\dot{x}_{\Gamma}(0)=\gamma$ that decreases with time to zero, i.e. $\dot{x}_{\Gamma}\left(t^{*}\right)=0, t^{*} \in[0, T], u\left(x_{\Gamma}, t^{*}\right)=1$.

In this case, you can put $F(u)=u \dot{x}_{\Gamma}(t)$. Then, looking for the partial solution of the diffusion equation (14) as a function

$$
u(x, t)=X(x)+\alpha x_{\Gamma}(t),
$$

satisfying the boundary conditions $u_{x}^{\prime}(0, t)=-\alpha x_{\Gamma}(t)$, $u_{x}^{\prime}(x, t)=0, x_{\Gamma}(t) \leq x \leq 1, t \in[0, T]$, we get the ratio $\alpha \dot{x}_{\Gamma}(t)=-\mu \dot{x}_{\Gamma}(t) X^{\prime \prime}(x)+\left(X+\alpha x_{\Gamma}(t)\right) \dot{x}_{\Gamma}(t)$.

Given $\dot{x}_{\Gamma}(t) \neq 0$, we rewrite it in the form

$$
\mu X^{\prime \prime}(x)-X=\alpha\left(x_{\Gamma}(t)-1\right),
$$

which is a non-homogeneous ordinary differential equation whose solution is sought as a sum $X(x)=X_{o}(x)+X_{H}(x)$, where $X_{o}(x)$ is the total solution of the homogeneous equation $\mu X^{\prime \prime}(x)-X=0$, and the function $X_{H}(x)$ is a partial solution of the inhomogeneous equation (18).

A homogeneous differential equation solution will be a function $X_{0}(x)=c_{1} e^{x / \sqrt{\mu}}+c_{2} e^{-x / \sqrt{\mu}}$, that can be 
used to find the general solution of equation (18) (for example, by the constant variation method).

Finally, let us consider another solution to equation (8). We will look for a solution characterized by the property that, as time $t \in[0, T]$ changes, the shape of the curve that sets the dependence of $u$ on $x$ does not change, and the curve itself moves from right to left with velocity $\lambda$. This is a solution in form of $u(x, t)=U(z)$ that allows you to enter a new variable $z=x+\lambda t$ and move on to the equation

$$
\lambda d u / d z=-k(t)^{d^{2} u / d z^{2}}+F(u) .
$$

Given $k(t)$ as a constant, that is $k(t)=k$, for every moment in time $t \in[0, T]$, one can obtain the solution of equation (19) based on the solution of the functional equation

$$
d u / d z=\exp (-\lambda u / k)\left(c_{0}+\int \exp (\lambda s / k) F(s) d s\right)
$$

which exists for arbitrary $\lambda \geq \lambda_{0}$ [12]. So, when $\lambda=\lambda_{0}$ we get the boundary shape of the curves with the properties described above.

The particular form of the solution of equation (19) will depend on the choice of the function $F(u)$ that needs further investigation.

\section{EXPERIMENTS}

To conduct numerical experiments, a computer program was developed that implements the technique proposed in the article. The developed software was used to solve the problem of distributing conditional information, taking into account the dynamics of the part of the population under the influence of information. Numerical modeling was carried out on the basis of the obtained formulas and using the method for solving the Cauchy problem for ordinary differential equations.

The calculations were carried out at various values of the parameters, in the presence and absence of influences in the form of an external information influence. Based on the original results, estimates of the level of information penetration in the target group were obtained.

\section{RESULTS}

Fig. 1 graphically illustrates an example of the spatialtemporal distribution of levels of perception of information in a population group, which is calculated on the basis of the hybrid model (1), (2) obtained by using the diffusion equation and using the Bailey model differential equation system (2).

Fig. 2 graphically illustrates an example of the spatialtemporal distribution of levels of perception of information in a population group, which is calculated using the hybrid model (8), (2) with $f(x, t)=\beta \dot{x}_{\Gamma}(t)$, obtained on the basis of the inhomogeneous diffusion equation and using the Bailey model differential equation system (2).

On the graphs, the S-shaped nature of the process of disseminating information is clearly visible, which indicates the adequacy of the results.

\section{DISCUSSION}

The use of models based on a hybrid system from the diffusion equation and a system of ordinary differential equations is an original technique that allows one to obtain estimates of solutions in problems of information dissemination. The adequacy of their use for modeling was tested on the processes of dissemination of flows of advertising information. As an alternative, the model of the influence of advertising on the basis of indicators of the dynamics of goods obtained taking into account statistical reports on the results of the activities of trading enterprises was considered [7]. The results of modeling the process of changing the levels of distribution of advertising information, taking into account indicators of sales of commercial products, were considered as reference. It should be noted that the results of numerical experiments of the dynamics parameters of the processes of changing the perception of information within the specified population groups and the processes of informational influence are taking into account the sales figures are very near. A common characteristic feature of the proposed models is the S-shape of information dissemination processes.

Unfortunately, one cannot talk about the identity of model results based on both approaches in the vast majority of experiments. This is easily explained by the absence of any specific information about the relationship between sales volumes and levels of remembering advertising. However, in our opinion, the proposed options for hybrid systems of the dynamics of the distribution of information levels based on the diffusion equation using special dynamic models are of certain interest and can be further refined taking into account new formal and informal relationships that use various ways of formalizing the external information influence.

\section{CONCLUSIONS}

This paper proposes an approach to the construction of hybrid mathematical models of the dynamics of information processes propagation in the target population, taking into account and without taking into account the impact on the process of information dissemination by external sources and other means.

Formalization is based on the idea of using hybrid mathematical models, which consist of the diffusion (penetration) equation and dynamic models, that describe the processes of change in the size of the contingent of the information dissemination environment. A scalar solution for a one-dimensional representation of a group contingent is considered. Various cases of formalization of external influence on the process of information dissemination are considered. 
Examples of numerical experiments to evaluate the level of impact based on the application of this approach are given, and their results are analyzed. The comparative analysis allows to confirm the existence of sufficient adequacy of model data and data obtained as a result of real observations of the processes of change in the perception of information within specific target population groups.

The scientific novelty of obtained results is that the proposed technique allows us to describe the levels of propagation, influence and storage of information in a group on the basis of the solution of the diffusion equation, the variation of the propagation intervals in which is determined by the additional relationships obtained from the solutions of the additional Bailey differential equation.
The practical significance of obtained results is that the proposed methodology form the basis for the development of the applied research project for the analysis of the distribution processes and the influence of information flows in social networks. The development of methods and approaches to support decision making in this direction is an important task that have being solved with the aim of testing concepts and technological solutions in the field of constructive assessment of the dynamics of information impact without creating physical analogues.

Prospects for further research are the development of new diffusion-type models that formalize the different nature of the influence of external factors on the processes of information dissemination, the study of the influence of delay and impulsive effects on the information process.

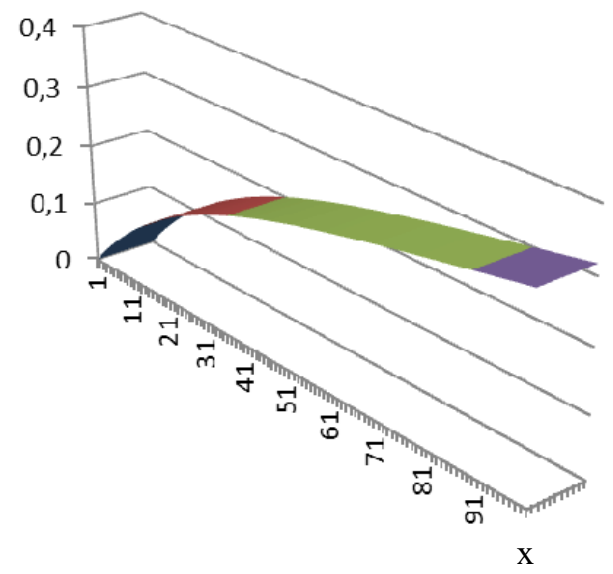

a

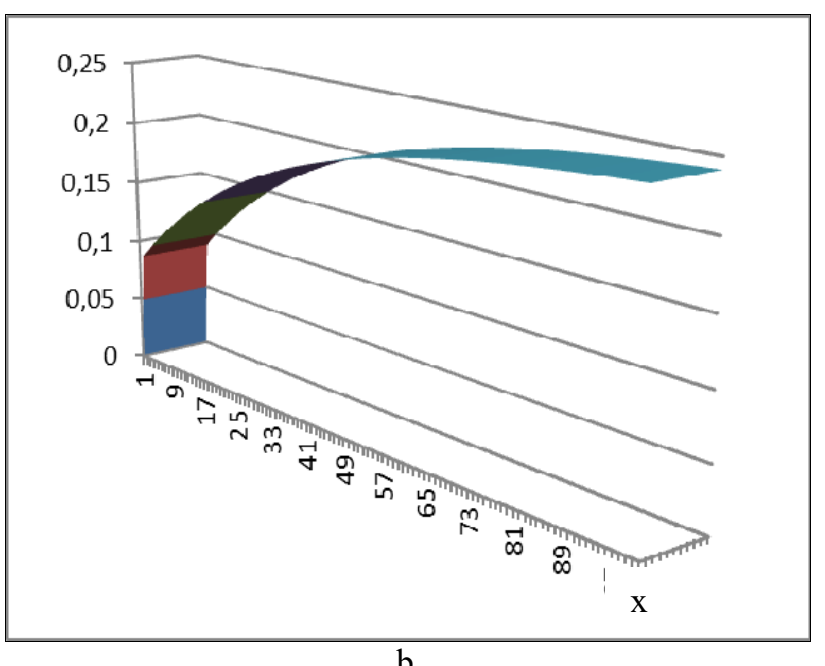

b

Figure 1 - The example of the spatial-temporal distribution of levels of perception of information in a population group, which is calculated on the basis of the hybrid model (1), (2): $\mathrm{a}-\alpha=0.001, \mu=0.5 ; \mathrm{b}-\alpha=0.1, \mu=0.05$.

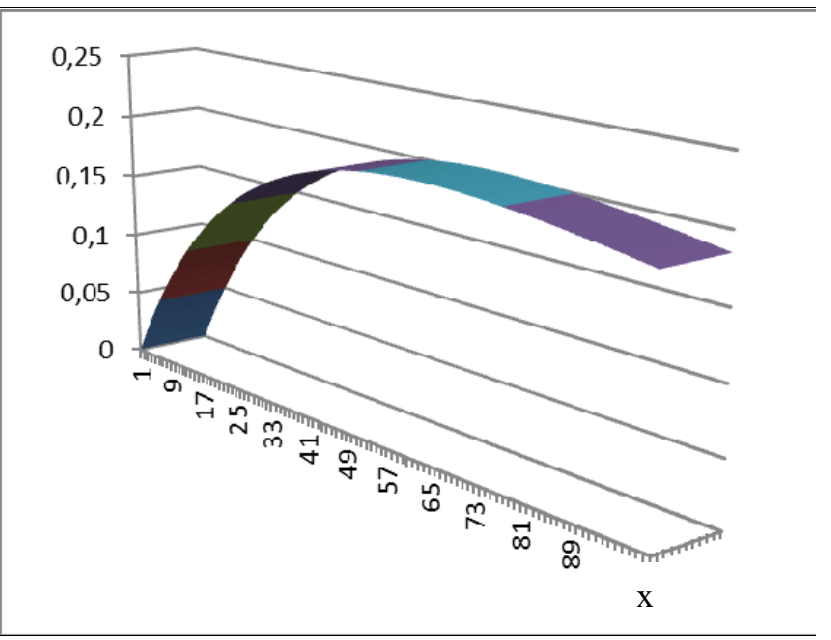

a

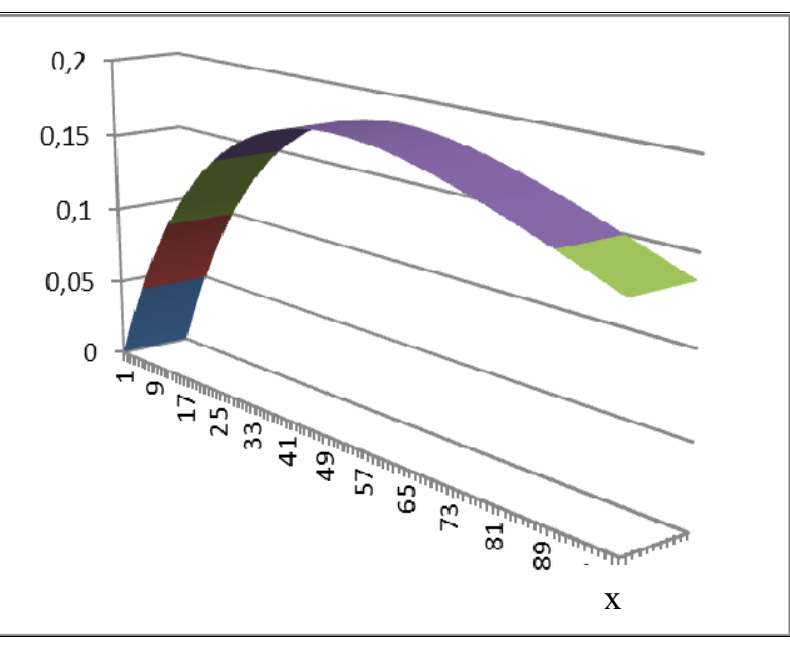

b

Figure 2 - The example of the spatial-temporal distribution of levels of perception of information in a population group, which is calculated using the hybrid model (8), (2) with $f(x, t)=\beta \dot{x}_{\Gamma}(t)$ :

$\mathrm{a}-\alpha=0.01, \mu=0.125, \beta=0.01 ; \mathrm{b}-\alpha=0.25, \mu=0.125, \beta=0.2$. 


\section{REFERENCES}

1. Smith R. Modelling Disease Ecology with Mathematics. Ottawa, American Institute of Mathematical Sciences, 2017, 291 p. ISBN-10: 1601330200,ISBN-13: 978-1601330208

2. Bellman R. Mathematical methods in medicine. Singapore, World Scientific Pub. Co. Inc., 1983, 268 p. ISBN-10: 9971950200, ISBN-13: 978-9971950200

3. Nowak A., Vallacher R. R. Social Processes, Computational Models of, Encyclopedia of Cognitive Science, 2006, pp. 81-84. DOI: 10.1002/0470018860.s00639

4. Quastler H. The emergence of biological organization. New Haven and London, Yale University Press, 1964, 83 p. ASIN B0000CMHJ2

5. von Scheel H. Zakaria M., von Rosing M. Social Media and Business Process Management, The Complete Business Process Handbook. Body of Knowledge from Process Modeling to BPM, 2015, Vol. I, pp. 381-398. DOI: 10.1016/B978-0-12-7999593.00018-5.

6. Ivohin, E. V., Adzhubey L. T. About the use of diffusion process models for description of information extension dynamics, Scientific Bulletin of Uzhgorod University. Series of Mathematics and Informatics, 2019, № 1 (34), pp.86-93. DOI: 10.24144/2616-2019.1(34).86-93.

7. Ivokhin E.V. On Formalization of Information Dissemination Processes Based on Hybrid Diffusion Models, Journal of Automation and Information Sciences, 2018, Vol. 50, No. 7, pp. 7986. DOI: $10.1615 / J A u t o m a t I n f S c i e n . v 50 . i 7.70$
8. Ivokhin E. V., Adzhubey L. T., Gavrylenko E. V. On the Formalization of Dynamics in Information Processes on the Basis of Inhomogeneous One-Dimensional Diffusion Models, Journal of Automation and Information Sciences, 2019, Vol. 51, No. 2, pp. 22-29. DOI: 10.1615/JAutomatInfScien.v51.i2.30

9. Ivohin, E. V., Adzhubey L. T. On the modeling of information distribution dynamics on the basis of homogeneous diffusion hybrid models, Scientific Bulletin of Uzhgorod University. Series of Mathematics and Informatics, 2019, No. 2(35), pp. 112 118. DOI: 10.24144/2616-7700.2019.2(35).112-118

10. Tikhonov A. N., Samarskii A. A. Equations of Mathematical Physics. Oxford, Pergamon Press Ltd, 1963, 776 p. ISBN-10: 0080102263, ISBN-13: 978-0080102269.

11. Hairer E., Norsett S. P., Wanner G.Solving Ordinary Differential Equations I: Nonstiff Problems (2nd ed.). Berlin, SpringerVerlag, 1993, 512 p. DOI: 10.1007/978-3-540-78862-1

12. Fikhtengolts G.M. Kurs differentsialnogo i integralnogo ischisleniya (in Russian). T.3. Moscow, FIZMATLIT, 2008, 728 p. ISBN-10: 5922104661 ISBN-13: 978-5922104661

13. Budak B. M., Samarskii A. A., Tikhonov A. N. A Collection of Problems on Mathematical Physics: International Series of Monographs in Pure and Applied Mathematics. Oxford, Pergamon Press Ltd, 2013, 782 p. DOI 10.1016/C2013-0-05314-5

Received 22.01.2020

Accepted 10.03.2020

УДК 004.942

\section{ДОСЛІДЖЕННЯ ДИНАМІКИ ПРОЦЕСІВ ПОШИРЕННЯ ІНФОРМАЦІЇ НА ОСНОВІ ДИФУЗІЙНИХ ГІБРИДНИХ} МОДЕЛЕЙ

Івохін Є. В. - д-р фіз.-мат. наук, професор, професор кафедри системного аналізу та теорії прийняття рішень Київського національного університету імені Тараса Шевченка, Київ, Україна.

Аджубей Л. Т. - канд. фіз.-мат. наук, доцент, доцент кафедри обчислювальної математики Київського національного університету імені Тараса Шевченка, Київ, Україна.

Гавриленко О. В. - канд. фіз.-мат. наук, доцент, доцент кафедри автоматизованих систем обробки інформації і управління Національного технічного університету України «Київський політехнічний інститут імені Ігоря Сікорського», Київ, Україна.

Науменко Ю. О. - канд. техн. наук, мол. наук. співр. кафедри системного аналізу та теорії прийняття рішень Київського національного університету імені Тараса Шевченка, Київ, Україна.

\section{АНОТАЦІЯ}

Актуальність. Розв'язання проблеми формалізації і вивчення розвитку процесів поширення інформації з плином часу і його вплив на на суспільство дуже важливо для забезпечення інформаційної безпеки. Необхідно використовувати принципово новий інструмент, який буде адекватно відображати стан динамічної складової процесу поширення інформації. Об'єктом дослідження є гібридні дифузійні моделі для формалізації динаміки процесів інформационного поширення та впливу. Метою роботи є дослідження математичних моделей процесів поширення інформації 3 метою моделювання динаміки зміни рівнів впливу інформації в різних цільових групах.

Метод. Запропоновано підхід до формалізації гібридних математичних моделей динаміки поширення інформаційних процесів в цільовій групі на основі дифузійних моделей. Для підвищення адекватності та надійності результатів, отриманих на основі побудованих моделей, пропонується застосовувати гібридні системи, засновані на дифузійних і динамічних моделях, що описують процес зміни розміру контингенту середовища поширення інформації. Запропонований метод дозволяє моделювати динамічні процеси спостереження за рівнем інформаційного впливу на основі рішень неоднорідних дифузійних рівнянь, зміна інтервалів просторової змінної в яких визначається додатковими співвідношеннями у вигляді системи диференціальних рівнянь. Розглянуто скалярний випадок однорідного і неоднорідного рівняння дифузії за умови одновимірного подання контингенту цільової групи. Наведено приклади застосування цього підходу, проаналізовані результати чисельних експериментів.

Результати. Розроблена методика дозволяє отримати оцінки рівня розповсюдження інформації в цільовій групі на основі використання моделей дифузійного процесу.

Висновки. Проведені експерименти підтвердили наявність достатньої адекватності модельних даних та даних, отриманих в результаті реальних спостережень за процесами зміни сприйняття інформації всередині конкретних цільових груп населення. Перспективами подальших досліджень $є$ розробка нових моделей дифузійного типу, які формалізують різний характер впливу зовнішніх факторів на процеси поширення інформації.

КЛЮЧОВІ СЛОВА: інформація, розповсюдження, метод аналогій, дифузійні гібридні моделі. 


\section{ИССЛЕДОВАНИЕ ДИНАМИКИ ПРОЦЕССОВ РАСПРОСТРАНЕНИЯ ИНФОРМАЦИИ НА ОСНОВЕ ДИФФУЗИОННЫХ ГИБРИДНЫХ МОДЕЛЕЙ}

Ивохин Е. В. - д-р физ.-мат. наук, профессор, профессор кафедры системного анализа и теории принятия решений Киевского национального университета имени Тараса Шевченко, Киев, Украина.

Аджубей Л. Т. - канд. физ.-мат. наук, доцент, доцент кафедры вычислительной математики Киевского национального университета имени Тараса Шевченко, Киев, Украина.

Гавриленко О. В. - канд. физ.-мат. наук, доцент, доцент кафедры автоматизированных систем обработки информации и управления Национального технического университета Украины «Киевский политехнический институт имени Игоря Сикорского», Киев, Украина.

Науменко Ю. О. - канд. техн. наук, мл. науч. сотр. кафедры системного анализа и теории принятия решений Киевского национального университета имени Тараса Шевченко, Киев, Украина.

\section{АННОТАЦИЯ}

Актуальность. Решение проблемы формализации и изучения развития процесса распространения информации с течением времени и его влияния на общество очень важно для обеспечения информационной безопасности. Необходимо использовать принципиально новый инструмент, который будет адекватно отражать состояние динамической составляющей процесса распространения информации. Объектом исследования являются гибридные диффузионные модели для формализации динамики процессов информационного распространения и влияния. Целью работы является исследование математических моделей процессов распространения информации с целью моделирования динамики изменения уровней влияния информации в разных целевых группах.

Метод. Предложен подход к формализации гибридных математических моделей динамики распространения информационных процессов в целевой группе на основе диффузионных моделей. Для повышения адекватности и надежности результатов, полученных на основе построенных моделей, предлагается применять гибридные системы, основанные на диффузионных моделях и динамических моделях, описывающих процесс изменения размера контингента среды распространения информации. Предложенный метод позволяет моделировать динамические процессы наблюдения за уровнем информационного воздействия на основе решения неоднородных диффузионных уравнений, изменение интервалов пространственной переменной в которых определяется дополнительными соотношениями в виде системы дифференциальных уравнений. Рассмотрен скалярный случай однородного и неоднородного уравнения диффузии при условии одномерного представления контингента целевой группы. Приведены примеры применения этого подхода, проанализированы результаты численных экспериментов.

Результаты. Разработанная методика позволяет получить оценки уровня распространения информации в целевой группе на основе использования моделей диффузионного процесса.

Выводы. Проведенные эксперименты подтвердили наличие достаточной адекватности модельных данных и данных, полученных в результате реальных наблюдений за процессами изменения восприятия информации внутри конкретных целевых групп населения. Перспективами дальнейших исследований являются разработка новых моделей диффузионного типа, которые формализуют различный характер влияния внешних факторов на процессы распространения информации.

КЛЮЧЕВЫЕ СЛОВА: информация, распространение, метод аналогий, диффузионные гибридные модели.

\section{ЛІТЕРАТУРА / ЛИТЕРАТУРА}

1. Smith R. Modelling Disease Ecology with Mathematics / R. Smith. - Ottawa: American Institute of Mathematical Sciences, 2017. - 291 p. ISBN-10: 1601330200,ISBN-13: 9781601330208

2. Bellman R. Mathematical methods in medicine. Singapore: World Scientific Pub. Co. Inc., 1983. - 268 p. ISBN-10: 9971950200, ISBN-13: 978-9971950200

3. Nowak A. Social Processes, Computational Models of / A. Nowak, R. R. Vallacher // Encyclopedia of Cognitive Science. - 2006. - P. 81-84. DOI: 10.1002/0470018860.s00639

4. Quastler H. The emergence of biological organization / H. Quastler. - New Haven and London: Yale University Press, 1964. -83 p. ASIN: B0000CMHJ2

5. von Scheel H. Social Media and Business Process Management / H. von Scheel, M. Zakaria, M. von Rosing // The Complete Business Process Handbook. Body of Knowledge from Process Modeling to BPM. - 2015. - Vol. I. - P. 381-398. DOI: 10.1016/B978-0-12-799959-3.00018-5.

6. Ivohin E. V. About the use of diffusion process models for description of information extension dynamics / E. V. Ivokhin, L. T. Adzhubey // Scientific Bulletin of Uzhgorod University. Series of Mathematics and Informatics. - 2019. - № 1 (34). - P 86-93. DOI: $10.24144 / 2616-2019.1(34) .86-93$.

7. Ivokhin E. V. On Formalization of Information Dissemination Processes Based on Hybrid Diffusion Models / E. V. Ivokhin, Yu. A. Naumenko / Journal of Automation and Information Sciences. - 2018. - Vol. 50, № 7. - P. 79-86. DOI: 10.1615/JAutomatInfScien.v50.i7.70

(C) Ivohin E. V., Adzhubey L. T., Gavrylenko O. V., Naumenko Yu. O., 2020 DOI 10.15588/1607-3274-2020-2-13
8. Ivokhin E. V. On the Formalization of Dynamics in Information Processes on the Basis of Inhomogeneous One-Dimensional Diffusion Models / E. V. Ivokhin, L. T. Adzhubey, E. V. Gavrylenko // Journal of Automation and Information Sciences. 2019. - Vol.51, No. 2. - P. 22-29. DOI: 10.1615/JAutomatInfScien.v51.i2.30

9. Ivohin E. V. On the modeling of information distribution dynamics on the basis of homogeneous diffusion hybrid models/ / E. V. Ivokhin, L. T. Adzhubey // Scientific Bulletin of Uzhgorod University. Series of Mathematics and Informatics. 2019. - № 2 (35). - P. 112-118. DOI: 10.24144/26167700.2019.2(35).112-118

10. Tikhonov A. N. Equations of Mathematical Physics / A. N. Tikhonov, A. A. Samarskii. - Oxford : Pergamon Press Ltd, 1963. - 776 p. ISBN-10: 0080102263, ISBN-13: 9780080102269 .

11. Hairer E. Solving Ordinary Differential Equations I: Nonstiff Problems (2nd ed.) / E. Hairer, S. P. Norsett, G.Wanner. - Berlin : Springer-Verlag, 1993. - 512 p. DOI: 10.1007/978-3-54078862-1

12. Fikhtengolts G. M. Kurs differentsialnogo i integralnogo ischisleniya (in Russian). T. 3 / G. M. Fikhtengolts. - M. : FIZMATLIT, 2008. - 728 p. ISBN-10: 5922104661 ISBN-13: 978-5922104661

13. Budak B. M. A Collection of Problems on Mathematical Physics: International Series of Monographs in Pure and Applied Mathematics/ B. M. Budak, A. A. Samarskii, A. N. Tikhonov. Oxford : Pergamon Press Ltd, 2013. - 782 p. DOI 10.1016/C2013-0-05314-5 